\title{
Acute and Chronic Testosterone Responses to Physical Exercise and Training
}

\author{
Eduardo Lusa Cadore and Luiz Fernando Martins Kruel \\ Exercise Laboratory Research, Physical Education School, \\ Federal University of Rio Grande do Sul \\ Brazil
}

\section{Introduction}

High-intensity physical training is a powerful stimulus to acute increases in blood steroid hormone levels (Ahtiainen et al., 2005; Cadore et al., 2008a, 2008b, 2009a; Häkkinen \& Pakarinen, 1994a, 1995; Staron et al., 1994). Moreover, strength training (ST) has been shown to stimulate greater increases in testosterone levels when compared to aerobic training (Copeland, et al., 2002; Tremblay et al., 2003), which can be explained by the powerful influence of the anaerobic glycolytic pathway in stimulating acute hormonal increases in response to exercise (Kraemer \& Ratamess, 2005). This stimulus features control mechanisms independent from luteinising hormone (LH) stimulation (Fahrner \& Hackney, 1998; Lu et al., 1997), and some factors related to the training session are directly associated with this response (Cadore et al., 2008c; Häkkinen et al., 1988; Häkkinen \& Pakarinen, 1995, Kraemer et al., 1993; Smilios et al., 2003, 2006).

Despite the well-known acute hormonal response to physical exercise (Kraemer et al., 1990; Hansen et al., 2001; Cadore et al., 2009c), data on resting concentrations remain controversial. Some studies demonstrate increased resting testosterone levels following ST (Ahtiainen et al., 2003; Häkkinen et al., 1998; Izquierdo et al., 2006; Kraemer et al., 1993; Kraemer et al., 1999; Marx et al., 2001; Staron et al., 1994), leading authors to suggest this type of training as a form of intervention for maintaining testosterone levels during ageing (Kraemer et al., 1999). However, increases in resting testosterone levels were not observed in middle-aged (Cadore et al. 2008a) or elderly people (Häkkinen et al., 2000, 2001a; Kraemer et al., 1999). Chronic adaptations to ST apparently occur at the level of cellular androgen receptors (ARs), given that ARs present on muscle cells seem to increase in number in response to this type of training (Inoue et al., 1994; Willoughby \& Taylor, 2004), and this adaptation may result in improved hormone-receptor interaction (Bamman et al., 2001; Willoughby \& Taylor, 2004).

Conversely, reductions in testosterone levels associated with increases in cortisol levels have been observed in response to aerobic training in athletes subjected to high-volume training (Maïmoun et al., 2003). These alterations may be associated with the overtraining process and consequent suppression of the hypothalamic-pituitary-gonadal and adrenocortical axis (Bell et al., 2001; Hu et al., 1999; Kraemer et al., 1995). Nevertheless, reductions in testosterone levels may occur without overtraining. This alteration may be transient, reflecting the variation in volume and training intensity, and it may be explained by changes in plasma volume (Hu et al., 1999; Kraemer \& Ratamess, 2005; Maïmoun et al., 2003). 
It has been suggested that the neuromuscular adaptations observed during ST (Häkkinen et al., 2000, 2001b; Tsolakiis et al., 2004) are partly mediated by acute responses to circulating testosterone levels resulting from the training session (Kraemer \& Ratamess, 2005) as well as modifications in the cellular receptors present on muscle cells (Ahtiainen et al., 2011; Kadi et al., 2000). Besides the known effects exerted by these hormones on muscle metabolism (Bhasin et al., 2001), the magnitude of increase in muscular strength in individuals subjected to strength training has been associated with testosterone concentration and other hormonerelated parameters (i.e., the testosterone:cortisol ratio and testosterone:sex hormone-binding globulin (SHBG)) (Cadore et al., 2010; Häkkinen et al., 1988, 2000; Häkkinen \& Pakarinen, 1993a, 1993b; Izquierdo et al., 2001). The figure 1 shows a Schematic diagram of the mechanism of training adaptations: anabolic process as adaptation to strength training and chronic catabolic process resulting from excessive volume of both strength and aerobic training.

Due to the possible importance of acute hormone responses, as well as chronic adaptation of androgen receptors due to strength training, it may be important to determine which aspects of training influence these responses to establish an optimum anabolic environment during a training session or period. Therefore, the objective of this chapter is to review existing data on the influence of testosterone levels on physical training and to determine which factors related to the training session are associated with the acute and chronic hormone responses the endocrine system to exercise.

\section{Testosterone and strength trainability}

Testosterone is a powerful stimulator of protein synthesis, specifically in the context of muscle metabolism (Griggs et al., 1989). Its effects are exerted through the interaction between the hormone and its specific receptor located on the muscle cell (Bamman et al., 2001). The main mechanism through which testosterone induces protein synthesis is the activation and induction of the proliferation of satellite cells, which subsequently incorporate into muscle fibres, resulting in an increase in myonuclear number (Kadi et al., 2000). Moreover, this hormone is capable of influencing strength production by stimulating the transition of type II fibres to a more glycolytic profile (Ramos et al., 1998), increasing the secretion of insulin-like growth factor I (IGF-I), mediated by its influence on the amplitude of growth hormone (GH) pulses (Bross et al., 1999) as well as its influence on the production of neurotransmitters that are important for muscle contraction (Kraemer et al., 1999).

Several studies demonstrate that among individuals subjected to the same volume and intensity of ST, those presenting higher testosterone levels achieve greater muscular strength and/or power following training (Ahtiainen et al., 2003; Cadore et al., 2010; Häkkinen et al., 1988; Häkkinen \& Pakarinen, 1993a). This suggests that the trainability of individuals is related to testosterone and hormonal parameters associated with this hormone, such as the testosterone:sex hormone-binding globulin (SHBG) ratio and the testosterone:cortisol ratio, as demonstrated by results obtained in published studies (Ahtiainen et al., 2003; Cadore et al., 2010; Häkkinen et al., 1988; Häkkinen \& Pakarinen, 1993a). Furthermore, in transversal studies that investigated middle-aged and elderly individuals, strength production was correlated to serum testosterone levels (Häkkinen \& Pakarinen, 1993a; Cadore et al., 2008a).

Häkkinen et al. (1988) investigated male weightlifting athletes (22.3 \pm 2.1 years) and observed a correlation between testosterone:cortisol and testosterone:SHBG ratios and the variations in maximum strength and rate of force development (RFD), respectively, as a result of ST ( $\mathrm{r}=$ 
0.77 and $\mathrm{r}=0.84, \mathrm{P}<0.05)$. In an investigation of the relationship between the endocrine system and strength production, Häkkinen \& Pakarinen (1993a) observed a correlation between maximum strength and testosterone levels as well as testosterone:SHBG ratio $(\mathrm{r}=0.62$ and 0.68 , respectively, $\mathrm{P}<0.01$ ). A study by Izquierdo et al. (2001) revealed that individuals with greater increases in isometric strength following ST also showed higher total $(r=0.78, P<$ $0.01)$ and free $(\mathrm{r}=0.71, \mathrm{P}<0.05)$ testosterone levels. The same trend was observed in data obtained by Ahtiainen et al. (2003) when evaluating highly trained men subjected to a 21-week ST program, where positive correlations were observed between the changes in isometric strength and total testosterone $(\mathrm{r}=0.84, \mathrm{P}<0.01)$, the testosterone:cortisol ratio $(\mathrm{r}=0.88, \mathrm{P}<$ $0.01)$ and the isometric strength development and free testosterone (pre-training values: $r=$ $0.78, \mathrm{P}<0.05$ and post-training values: $\mathrm{r}=0.82, \mathrm{P}<0.05$ ). A study conducted in our laboratory by Cadore et al. (2008a) showed significant correlations between testosterone:SHBG ratios and DHEA concentrations as well as strength production in bench press, leg press and squat exercises $(\mathrm{r}=0.55$ to $0.82, \mathrm{P}<0.05$ to $\mathrm{P}<0.001)$ in trained and untrained middle-aged men. In another study, Cadore et al. (2010) showed significant correlations between increases in the strength of knee extensors and average basal total testosterone levels throughout the training period ( 3 measurements in 12 weeks of training) $(\mathrm{r}=0.94, \mathrm{P}<0.01)$ and the average total testosterone:cortisol ratio $(\mathrm{r}=0.93, \mathrm{P}<0.01)$. Table 1 shows the results obtained from studies where correlations between hormonal parameters and variables related to muscle strength were identified. One aspect that must be emphasised is that other structural factors, such as pennation angle and fibre type composition, may interfere with strength production (Ramos et al., 1998), just as the volume and intensity of ST largely influence the increase in strength resulting from training (Marx et al., 2001).

\begin{tabular}{|c|c|}
\hline Author & Strength performance vs. sex hormonal parameters \\
\hline $\begin{array}{l}\text { Ahtianinen } \text { et al., } \\
2003\end{array}$ & $\begin{array}{l}\uparrow \text { MVC after ST with TT and TT:COR ratio }(\mathrm{r}=0.84 \text { and } 0.88, \mathrm{P}<0.01) \text {, and } \\
\text { MVC after ST with FT post training }(\mathrm{r}=0.82, \mathrm{p}<0.05)\end{array}$ \\
\hline $\begin{array}{l}\text { Cadore } \text { et al., } \\
2008 \text { a }\end{array}$ & $\begin{array}{l}\text { Squat } 1 \text { RM values with TT:SHBG and DHEA before }(r=0.71 \text { and } 0.65 \text {, } \\
\text { respectively) and after ST bout ( } r=0.76 \text { and } 0.82 \text {, respectively) }(\mathrm{p}<0.01 \text { to } 0.05) \text {. }\end{array}$ \\
\hline Cadore et al., 2010 & $\begin{array}{l}\uparrow \text { knee extension } 1 \mathrm{RM} \text { values after ST with TT and TT:COR ratio }(\mathrm{r}=0.94 \\
\text { and } 0.93 \text {, respectively, } \mathrm{p}<0.01)\end{array}$ \\
\hline $\begin{array}{l}\text { Häkkinen \& } \\
\text { Pakarinen, 1993a }\end{array}$ & TT and TT:SHBG with MVC and RFD $(r=0.66$ to $0.69, \mathrm{p}<0.01)$ \\
\hline $\begin{array}{l}\text { Häkkinen \& } \\
\text { Pakarinen, 1993b }\end{array}$ & $\begin{array}{l}\uparrow \text { MVC after ST with TT and TT:COR ( } r=0.57 \text { and } 0.61 \text {, respectively, } \\
\mathrm{p}<0.05)\end{array}$ \\
\hline $\begin{array}{l}\text { Häkkinen et al., } \\
1988\end{array}$ & $\begin{array}{l}\text { Annual average of TT:COR ratio and MVC }(\mathrm{r}=0.77, \mathrm{p}<0.05) \text {; and, annual } \\
\text { average of TT:SHBG ratio and } \uparrow \text { RFD after ST }(\mathrm{r}=0.84, \mathrm{p}<0.05)\end{array}$ \\
\hline $\begin{array}{l}\text { Häkkinen et al., } \\
2000\end{array}$ & $\begin{array}{l}\uparrow 1 \text { RM values after ST with FT and TT ( } r=0.55 \text { and } 0.43 \text {, respectively, } \\
\mathrm{p}<0.05)\end{array}$ \\
\hline $\begin{array}{l}\text { Izquierdo et al., } \\
2001\end{array}$ & $\uparrow$ MVC after ST with TT and FT $(\mathrm{r}=0.78$ and 0.71 , respectively, $\mathrm{p}<0.01)$ \\
\hline
\end{tabular}

Table 1. Relatioship between sex hormonal parameters and strength performance. TT: total testosterone; FT: free testosterone; COR: cortisol; DHEA, dehidroepiandrosterone; SHBG: sex hormone binding globuline; $\uparrow:$ increases; MVC: maximal voluntary contraction (maximal isometric strength); and, 1 RM: one-maximum repetition (maximal dynamic strength); ST: strength training. 


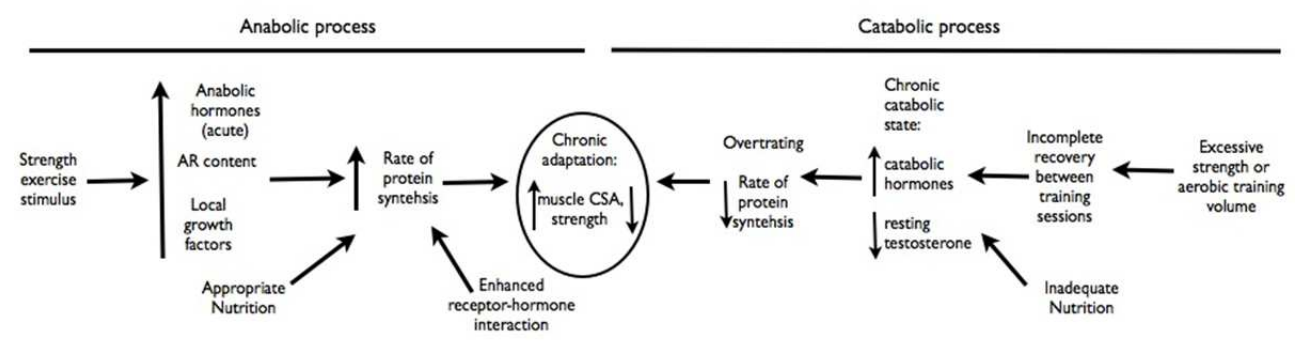

Fig. 1. Schematic diagram of the mechanism of training adaptations: anabolic process as adaptation to strength training and chronic catabolic process resulting from excessive volume of both strength and aerobic training. AR, androgen receptor; CSA, cross-sectional area.

\section{Acute testosterone responses to physical exercise}

Acute testosterone responses to ST exhibit plasticity, and their pattern depends on factors related to the training session, such as volume, intensity, method (i.e., single or multiple sets) (Cadore et al., 2009a; Häkkinen \& Pakarinen, 1993a; McCaulley et al., 2009), type of muscle contraction (Durand et al., 2003; Kraemer et al., 2006) and muscle mass involved (Häkkinen et al., 1998), as well as factors such as age (Kraemer et al., 1999; Cadore et al., 2009a) and the individual's level of training (Ahtiainen et al., 2003; Cadore et al., 2008a, 2009; Kraemer et al., 1999). The response of testosterone levels to ST may expose the skeletal musculature to an elevated peripheral hormonal concentration, which may improve the interaction between the hormone and its cellular receptors (Hoffman et al., 2003, Willoughby \& Taylor, 2004). Regarding aerobic training, even though the importance of the anabolic hormone response remains unclear, it seems that testosterone is more responsive to higher intensity exercises (Enea et al., 2009) and a longer duration of exercises (Harris et al., 1989; Trembley et al., 2005).

\subsection{Possibles physiological mechanisms for the stimulus}

The response of testosterone levels to exercise sessions may reflect certain regulatory mechanisms in addition to the processes that regulate the secretion of this hormone at rest (Fahrner and Hackney, 1998; Lu et al., 1997). A study conducted by Lu et al. (1997) demonstrated that exercise-induced increase in testosterone levels in male rats correlated with an increase in blood lactate levels. Following this observation, the authors proceeded to conduct an in vitro study where lactate was infused into the rats' testes, and a dosedependent increase in testosterone was observed. Methods of ST aimed at achieving muscle hypertrophy or resistance have been shown to cause high lactate production (McCaulley et al., 2009; Smilios et al., 2003), suggesting a strong relationship between the mechanism of testosterone increase and lactate stimulation in the testes ( $\mathrm{Lu}$ et al., 1997).

Other mechanisms may be responsible for the exercise-induced increase in testosterone levels, among which are increased sympathetic activity in response to exercise (Fahrner and Hackney, 1998) and blood flow and vasodilation related to the release of nitric oxide, which increases hormone secretion (Meskaitis et al., 1997). Even though various studies have used different strength training exercise protocols, Kraemer et al. (1999) and Ahtiainen et al. 
(2003) suggest that these mechanisms may also be mediators of testosterone increase in response to this type of training.

\subsection{The influence of strength training variables on testosterone responses}

It may be stated that the hormonal response to exercise is connected to certain characteristics inherent to the training session, such as the number of sets and repetitions, the relative intensity (percentage of 1 maximum repetition - $1 \mathrm{RM}$ ) and time intervals (McCaulley et al., 2009). The amount of work done during ST may be a determining factor in the acute hormone response, leading to an optimum combination of anabolic and catabolic hormone stimulation. This, in turn, may result in a more favourable environment for neuromuscular adaptations to training, resulting in increases in muscle strength and mass (Smilios et al., 2003).

The preponderant influence of volume on the hormonal response to different training methods was observed by Häkkinen and Pakarinen (1993b), who compared the hormonal response to a session involving 20 sets of $1 \mathrm{RM}$ with a session composed by 10 sets of 10 repetitions at $70 \%$ of $1 \mathrm{RM}$; both ST bout were conducted with 3-minute intervals between sets. The authors observed a significant increase $(\mathrm{P}<0.05)$ in total $(22 \%)$ and free $(23 \%)$ testosterone in response to the high-volume training and no increase in the training session that included a higher load and fewer repetitions. Smilios et al. (2003) showed that the hormone response observed in young men increased as the number of sets in each session increased, approaching maximum strength, muscle hypertrophy and resistance. These authors observed that when the number of sets was increased from 4 to 6, the anabolic hormone levels stabilised, while cortisol levels continued to increase. Their results suggest that modifying the volume of a ST session causes alterations in the balance between anabolic and catabolic hormones. When considering different training methods, McCaulley et al. (2009) observed a higher total testosterone response to muscle hypertrophy protocols when compared to protocols that aimed at developing maximum strength and power, despite equalisation of the total work load for each session (load $\mathrm{x}$ sets $\mathrm{x}$ repetitions). When investigating the influence of the total muscle mass involved in training, Häkkinen et al. (1998b) demonstrated a greater testosterone response in young and elderly men using protocols involving simultaneous use of the lower and upper limbs (27\%). However, an increase in hormone levels was also observed for protocols that involved the upper and lower limbs separately $(\mathrm{P}<0.01)$, indicating that the greater the amount of muscle mass involved, the greater the acute total testosterone response.

Regarding the influence of resting intervals on the acute hormone response, the smaller the interval between sets, the greater the stimulus (Kraemer et al., 1990). Nevertheless, when the sets are performed with maximum repetitions, the interval appears to have no influence within a certain intensity range, as demonstrated by Ahtiainen et al. (2005), who showed that there was no difference in acute hormone response between two protocols of $10 \mathrm{RM}$ with 2- and 5-minute intervals. Notwithstanding, sessions with moderate to high intensity that involve multiple sets and short time intervals, during which energy is derived mainly from glycolytic lactate metabolism, appear to be the greatest stimulus for the steroid hormone response to ST.

Little is known about the influence of combined aerobic and strength training (i.e., concurrent training) on the acute testosterone response. A study by Goto et al. (2005) demonstrated that the $\mathrm{GH}$ response to strength training was found to be suppressed by prior aerobic training. However, no differences were observed in strength training-induced 
testosterone concentrations, with or without prior aerobic training, possibly due to the lowvolume protocol used in the study. However, unpublished data from our laboratory show that the manipulation of the order of modalities (strength and aerobic) may, in fact, influence the testosterone response produced by concurrent training sessions. A significant increase was observed in both protocols following the first modality, though levels remained high only at the end of the training session when the protocol involved aerobic training followed by strength training; the same response was not observed when strength training was performed before aerobic training. When comparing acute testosterone responses to strength and aerobic training, some studies show that strength training appears to stimulate greater increases in testosterone levels when compared to aerobic training (Copeland et al., 2002, Tremblay et al., 2003). In a previous study (Cadore et al., 2009a), we showed significantly higher salivary free testosterone responses to water-based resistance exercise compared with water-based aerobic exercise in both young and elderly healthy men. These results can be explained by the powerful influence of the anaerobic glycolytic pathway on acute hormonal increases in response to exercise (Kraemer \& Ratamess, 2005).

\subsection{The Influence of age and training status}

The profile of the population subjected to training sessions is one of the factors that influence hormone response to ST. Studies aimed at investigating this response in different age groups have mainly observed lower responses in elderly individuals as demonstrated by Kraemer et al. (1999). For instance, when comparing acute total and free testosterone responses in groups of men aged $30 \pm 5$ and $62 \pm 3$ years, Kraemer et al. (1999) demonstrated that even though both groups showed an increase in free testosterone, a lower testosterone response was observed in the elderly group. According to these authors, the reduced response is associated with andropause, which is characterised by a smaller number and decreased secretory capacity of Leydig cells due to ageing. Similar results were observed by Cadore et al. (2009a), where elderly individuals showed significantly lower free-testosterone responses to water-based resistance exercise than young men.

The individual's training status may also influence the response of the endocrine system to ST (Cadore et al., 2008a, 2009b; Kraemer et al., 1992), given that different anabolic responses may occur before and after a period of ST. Kraemer et al. (1992) investigated weightlifting male athletes aged $17 \pm 2$ years and observed that individuals with more than 2 years of training presented higher acute testosterone responses. A study by Cadore et al. (2008a) observed different patterns of hormone response in trained and untrained middle-aged men $(40 \pm 4$ years) after a ST protocol. Significant increases in free testosterone $(27 \%)$ were observed in members of the trained group, whereas significant increases in both total $(28 \%)$ and free $(22 \%)$ testosterone as well as DHEA $(127 \%)$ were observed in the untrained group $(\mathrm{P}<0.05)$. These results may suggest a higher capacity for testosterone dissociation from carrier proteins, increasing the bioactivity of the hormone without the need for an increase in production. A study by Kraemer et al. (1999) showed higher free testosterone responses in young and elderly individuals following 10 weeks of periodic strength training. Some results suggest the existence of specific responses to certain types of training, as demonstrated in a study developed by Tremblay et al. (2003). The study showed greater increases in anabolic hormone levels in response to strength training in strength-trained subjects when compared to aerobically trained individuals, whereas aerobically trained subjects produced higher hormonal responses to aerobic exercise when compared to strength-trained individuals. 
However, the influence of the training status on the testosterone response to ST was not found in many studies. When submitting untrained and previously strength-trained individuals to a 21-week strength training protocol, Ahtiainen et al. (2003) observed similar alterations in total and free testosterone for both groups before and after training. This discrepancy may be due to factors such as sample profile, exercise protocol or potential changes in plasma volume. Moreover, testosterone responses to this type of exercise may be influenced by the relationship of the hormone with its cellular receptors, given that this interaction appears to be greater in trained individuals and that they thus may not require the same magnitude of an acute response in order to obtain an optimum hormone-receptor interaction (Ahtiainen et al., 2011; Willoughby \& Taylor, 2004).

\section{Chronic endocrine adaptations to physical training}

\subsection{Basal testosterone adaptations induced by strength training}

While some studies demonstrate an increase in the resting levels of testosterone as an adjustment to ST (Izquierdo et al., 2006; Kraemer et al., 1995; Nicklas et al., 1995; Raastad et al., 2003; Tsolakis et al., 2004), other studies have observed no significant differences in this parameter (Ahtiainen et al., 2003; Hansen et al., 2001; Hickson et al., 1994). So far, available data indicate that only young individuals are capable of altering their resting hormone concentrations (Häkkinen et al., 1988; Staron et al., 1994; Tsolakis et al., 2004), whereas middle-aged and elderly individuals show no significant changes in such parameters (Häkkinen \& Pakarinen, 1994; Häkkinen et al., 2000; 2001a; Izquierdo et al., 2006; Ryan et al., 1994). Increases in resting levels of testosterone seem to occur during periods of highvolume (Kramer et al., 1995; Marx et al., 2001) and high-intensity training (Staron et al., 1994; Kraemer et al., 1998; Raastad et al., 2003). These changes may occur in men (Häkkinen et al., 1988) and women (Marx et al., 2001) in response to long (Häkkinen et al., 1988; Marx et al., 2001) or short training periods (Staron et al., 1994; Kraemer et al., 1998).

The influence of training volume on chronic adaptations of basal testosterone was described in a study by Marx et al. (2001), which 34 women ( $22 \pm 5$ years) were evaluated before and after performing a 24-week ST protocol. In this study, resting levels of testosterone were measured in order to compare groups of ST performing single vs. multiple sets. The results showed an increase in testosterone in both training groups, and the first adaptations took place after 12 weeks of training. However, after 24 weeks of training, only the multiple sets group had further increases in their resting testosterone levels, which was higher in this point than after 12 weeks, and higher than the single set ST group. Even though the performance of high-volume ST sessions may induce higher acute increases in catabolic hormones (Smilios et al., 2003), the study developed by Marx et al. (2001) demonstrated that high-volume and high-intensity ST may lead to higher chronic increases in anabolic hormones compared to low-volume ST. This may contribute to the greater strength production observed in individuals who trained with multiple sets when compared to those who trained with simple sets (Kemmler et al., 2004).

The Table 2 shows subjects characteristics, training protocol and results from some of the studies that have investigated resting hormone adaptations to ST. Nevertheless, modifications in resting concentrations appear to be transient, resulting from the increase or decrease in intensity and, mainly, in volume (Ahtiainen et al., 2003). However, the precise role of resting testosterone concentrations in neuromuscular adaptation to training is yet to be determined. 


\begin{tabular}{|c|c|c|c|}
\hline Author & Subjects & Training protocol & Results \\
\hline $\begin{array}{l}\text { Ahtiainen et } \\
\text { al., } 2003\end{array}$ & $\begin{array}{l}\text { Young previously } \\
\text { trained and untrained } \\
\text { men }\end{array}$ & $\begin{array}{l}21 \text { weeks, } 2 \\
\text { times/week, 8-10 RM }\end{array}$ & $\begin{array}{l}\uparrow \text { FT in trained after } 14 \\
\text { weeks; no modifications } \\
\text { after } 21 \text { weeks }\end{array}$ \\
\hline $\begin{array}{l}\text { Cadore et al., } \\
\text { 2008a }\end{array}$ & $\begin{array}{l}\text { Middle-aged long-term } \\
\text { trained and untrained } \\
\text { men }\end{array}$ & $\begin{array}{l}10 \pm 5 \text { years of strength } \\
\text { training, } 4 \text { times a } \\
\text { week, 8-12 RM }\end{array}$ & $\begin{array}{l}\text { No difference at rest, } \\
\text { different responses to } \\
\text { exercise }\end{array}$ \\
\hline $\begin{array}{l}\text { Häkkinen et } \\
\text { al., 2001a }\end{array}$ & Elderly men & $\begin{array}{l}21 \text { weeks, } 40-80 \% \text { of } 1 \\
\text { RM }\end{array}$ & No modifications \\
\hline $\begin{array}{l}\text { Häkkinen et } \\
\text { al., } 1988\end{array}$ & $\begin{array}{l}\text { Elite powerlifters } \\
\text { young men }\end{array}$ & $\begin{array}{l}\text { Two years, } 5 \\
\text { times/week }\end{array}$ & $\uparrow \mathrm{TT}$ \\
\hline $\begin{array}{l}\text { Staron et al., } \\
1994\end{array}$ & Young men and women & $\begin{array}{l}8 \text { weeks, } 3 \text { times/week, } \\
6-12 \text { RM }\end{array}$ & $\uparrow \mathrm{TT}$ in men \\
\hline $\begin{array}{l}\text { Häkkinen \& } \\
\text { Pakarinen, } \\
1994\end{array}$ & $\begin{array}{l}\text { Middle-aged and } \\
\text { elderly men and } \\
\text { women }\end{array}$ & $\begin{array}{l}12 \text { weeks, } 3 \\
\text { times/week, } 40-80 \% \text { of } \\
1 \text { RM }\end{array}$ & No modifications \\
\hline $\begin{array}{l}\text { Izquierdo et al., } \\
2001\end{array}$ & Young men and women & $\begin{array}{l}16 \text { weeks, } 3 \\
\text { times/week, } 50-80 \% \text { of } \\
1 \text { RM }\end{array}$ & No modifications \\
\hline $\begin{array}{l}\text { Kraemer et al., } \\
1995\end{array}$ & Military young men & $\begin{array}{l}12 \text { weeks, } 4 \\
\text { times/ week, 3-10 RM, } \\
\text { strength vs. concurrent } \\
\text { training }\end{array}$ & $\begin{array}{l}\uparrow \mathrm{TT} \text { after concurrent } \\
\text { training }\end{array}$ \\
\hline $\begin{array}{l}\text { Kraemer et al., } \\
1999\end{array}$ & Young and elderly men & $\begin{array}{l}10 \text { weeks, } 3 \\
\text { times/week, 3-15 RM }\end{array}$ & $\uparrow \mathrm{FT}$ jovens \\
\hline $\begin{array}{l}\text { Marx et al., } \\
2001\end{array}$ & Young women & $\begin{array}{l}24 \text { weeks, } 3-15 \text { RM, } \\
\text { single vs. } 3 \text { sets per } \\
\text { exercise }\end{array}$ & $\begin{array}{l}\uparrow \mathrm{TT} \text { in both groups after } \\
12 \text { weeks, higher after } 3 \\
\text { sets training group }\end{array}$ \\
\hline $\begin{array}{l}\text { Nicklas et al., } \\
1995\end{array}$ & $\begin{array}{l}\text { Middle-aged and } \\
\text { elderly men }\end{array}$ & $\begin{array}{l}16 \text { weeks, } 3 \\
\text { times/week, 5-15 RM }\end{array}$ & No modifications \\
\hline $\begin{array}{l}\text { Ryan et al., } \\
1994\end{array}$ & Elderly men & $\begin{array}{l}16 \text { weeks, } 3 \\
\text { times/week, 5-15 RM }\end{array}$ & No modifications \\
\hline
\end{tabular}

Table 2. Testosterone modifications at rest after strength training: TT: total testosterone; FT: free testosterone; $\uparrow:$ increases; RM: maximal repetitions.

\subsection{Changes in circulating testosterone in response to aerobic training}

With regards to aerobic training, studies have demonstrated that endurance athletes have lower testosterone levels when compared to sedentary individuals (Strüder et al., 1998; Maïmoun et al., 2003). However, Strüder et al. (1998) showed that although testosterone levels were indeed lower in elderly male runners compared to age-matched sedentary subjects, the same was not true for previously sedentary subjects who performed aerobic training for 20 weeks 3 times per week with an intensity of 50 to $65 \%$ of aerobic power. A previous study conducted in our laboratory (Cadore et al., 2010) demonstrated a significant reduction in free testosterone in elderly men following 12 weeks of aerobic training on a 
cycle ergometer 3 times per week with intensity varying between 55 and $85 \%$ of aerobic power $(9.7 \pm 2.8$ vs. $7.9 \pm 3.0 \mathrm{pg} / \mathrm{mL}, \mathrm{P}<0.01)$. Possible discrepancies between the results of different studies may reflect the different intensities and volumes used, given that the intensity used by Strüder et al. (1999), for instance, was lower than the intensity used in our study (Cadore et al., 2010). However, in animal models, Hu et al. (1999) observed a significant reduction in testosterone levels in rats submitted to continuous swimming for 3 weeks. Levels were restored to normal following 6 weeks of training, suggesting an adjustment to training on $\mathrm{LH}$ secretion in the endocrine system that was associated with negative feedback. Even though testosterone reduction during aerobic training has not been clearly demonstrated, it is possible that a certain amount of time is necessary for the endocrine system to adapt to the volume and intensity of training when these factors exceed a certain stimulus threshold (Calbet et al., 1993; Kraemer \& Ratamess, 2005; Maïmoun et al., 2003).

Though high-volume physical training may result in the suppression of testosterone via direct inhibition due to the effect of cortisol on the testes (Brownlee et al., 2005), this does not completely explain the occurrence of testosterone reduction with aerobic training, given that increases in basal cortisol levels and the consequent testicular suppression are most commonly related to overtraining. In fact, testosterone levels have been shown to be reduced in endurance athletes with no alterations in cortisol levels (Maïmoun et al., 2003) as well as in non-athletes subjected to aerobic training (Cadore et al. 2010). Furthermore, other mechanisms, such as hypervolemia, increased utilisation of the hormone by muscle tissue and increased hepatic degradation of the hormone, may be responsible for the decrease in testosterone levels that result from endurance training (Izquierdo et al., 2004).

\subsection{Changes in muscle cell androgen receptors}

Evidence shows that cell adjustments may be key factors for training-induced hypertrophy (Ahtiainen et al., 2011; Deschenes et al., 1994; Inoue et al., 1993, 1994; Kadi et al., 2000; Bamman et al., 2001; Willoughby \& Taylor, 2004; Ratamess et al., 2005). Some of these adjustments correspond to an increase in the number of androgen receptors (AR) in the muscle, and they are apparently dependent on the pattern of acute testosterone response to exercise (Willoughby \& Taylor, 2004). A greater number of ARs and an increased sensitivity of these receptors to the hormone may improve the trophic effects of testosterone on target cells (Kadi et al., 2000). Inoue et al. (1993) subjected male rats to training using electrical stimulation and demonstrated that muscle hypertrophy occurred in parallel with a significant increase in cellular ARs. In a different study, Inoue et al. (1994) observed that the suppression of androgen receptors by receptor antagonists reduced the increase in muscle mass obtained with electrical stimulation.

Kadi et al. (2000) measured the number of ARs per area of muscle fibre in the superior trapezius and the vastus lateralis muscle of high-performance weightlifting men. The sample was composed of trained individuals with ( $31 \pm 3$ years) and without ( $28 \pm 8$ years) the use of exogenous anabolic steroids as well as untrained individuals ( $23 \pm 3$ years). Results showed higher numbers of ARs per area of muscle fibre in the superior trapezius of individuals from both trained groups when compared with untrained individuals. Moreover, individuals using exogenous anabolic steroids presented higher values than those that were only training $(\mathrm{P}<0.05)$. Surprisingly, these differences were observed only in the superior trapezius. The proportion between the different types of muscle fibres present in each of the evaluated muscle groups (i.e., type I and type II) may have influenced the different behaviours of the 
androgen receptors in response to training. In fact, while studying rats subjected to strength training, Deschenes et al. (1994) were only able to observe an increase in the number of ARs in muscles with a predominance of fast glycolytic fibres, whereas muscles with a predominance of slow oxidative fibres showed decreased numbers of ARs.

Willoughby \& Taylor (2004) conducted a study where 18 young men were subjected to 3 sessions of ST with 3 sets of 8 to $10 \mathrm{RM}$. Results showed a significant increase in protein synthesis, AR expression and AR messenger RNA following the training sessions, where values increased up to $202 \% 48$ hours after the third session. Furthermore, the study revealed a correlation between testosterone increase (significant following all sessions) and an increase in the number of receptors $(\mathrm{r}=0.89, \mathrm{P}<0.05)$. These results suggest that the hormone-receptor complex constitutes an important element in the mechanism responsible for mediating the adjustments to strength training, such as an increase in muscle strength and exercise-induced hypertrophy (Inoue et al., 1993; Kadi et al., 2000; Willoughby \& Taylor 2004).

\section{Conclusion}

As noted in the studies presented in this chapter, there is a connection between the trainability of individuals subjected to ST and their levels of circulating testosterone. However, factors related to the training sessions and population profile seem to influence acute and chronic hormone responses, which result in a plasticity in the pattern of testosterone response to physical exercise, particularly strength training. Among the types of strength training sessions, high-volume protocols with moderate to high intensity (70$85 \% 1 \mathrm{RM}$ ), which are typically used to achieve muscle hypertrophy and predominantly rely on the glycolytic lactate metabolic pathway, appear to stimulate greater responses. Moreover, the increase in the number of ARs appears to have a key role in muscle hypertrophy observed with ST. However, determining which factors might be related to the hormone response to ST may be of great importance for the prescription of a training session and determination of the optimum period that will optimise the anabolic environment determined by testosterone and thus maximise the neuromuscular adaptations resulting from strength training.

\section{Acknowledgements}

We thank specially to CAPES and CNPq government associations for their support to this project.

\section{References}

Ahtiainen J.P.; Pakarinen, A.; Alen, M.; Kraemer, W.J. \& Häkkinen, K. (2003). Muscle hypertrophy, hormonal adaptations and strength development during strength training in strength-trained and untrained men. European Journal of Applied Physiology, Vol. 89, No. 6 (Aug 2003) pp. 555-63, ISSN 1419-6339

Ahtiainen J.P.; Pakarinen, A.; Alen, M.; Kraemer, W.J.; \& Häkkinen, K. (2005). Short vs. long rest period between the sets in hypertrophic resistance training: influence on muscle strength, size, and hormonal adaptations in trained men. Journal of Strength and Conditioning Research, Vol 19, No. 3, pp. 572-582, ISSN 1064-8011 
Ahtiainen J.P.; Hulme, J.J.; Kraemer, W.J.; Lehti, M.; Nyman, K.; Selanne, H.; Alen, M.; Pakarinen, A.; Komulainen, J.; Kovanen, V.; Mero, A.A. \& Häkkinen, K. (2011). Heavy resistance exercise training and skeletal muscle androgen receptor expression in younger and older men. Steroids, Vol. 76, No. 1-2 (Jan 2011), pp. 183192, ISSN 0039-128X

Bamman, M.M.; Ship, J.R.; Jiang, J.; Gower, B.A.; Hunter, G.R.; Goodman, A.; McLafferty, J.R. \& Urban, R.J. (2001). Mechanical load increases muscle IGF-I and androgen receptor mRNA concentration in humans. American Journal of Physiology: Endocrinology and Metabolism, Vol. 280, No. 3 (Mar 2001), pp. 383-90, ISSN 0193-1849

Bell, G.J.; Syrotuik, D.; Martin, T.P.; Burnham, R. \& Quinney, H.A. (2000). Effect of concurrent strength and endurance training on skeletal muscle properties and hormone concentrations in humans. European Journal of Applied Physiology, Vol. 81, No. 5 (mar 2000), pp. 418-427, ISSN 1419-6339

Bhasin, S.W.; Woodhouse, L.; Casaburi, R.; Singh, A.B.; Bhasin, D.; Berman, N., Chen, X.; Yarasheske, K.E.; Magliano, L.; Dzekov, C.; Dzekov, J.; Bros, R.; Philips, J.; SinhaHikim, I.; Shen, R. \& Storer, T.W. (2001). Testosterone dose-response relationships in healthy young men. American Journal of Physiology: Endocrinology Metabolism, Vol. 281, No. 6, (Dec 2001), pp. 1172-1181, ISSN 0193-1849

Bross, R.; Javanbakht, M. \& Bhasin, S. (1999). Anabolic intervention for aging-associated sarcopenia. The Journal of Clinical Endocrinology and Metabolism, Vol. 84, No. 10, pp. 3420-3430, ISSN 0021-972X

Brownlee, K.K.; Moore, A.W. \& Hackney, A.C. (2005). Relationship between circulating cortisol and testosterone: influence of physical exercise. Journal of Sports Science and Medicine, Vol. 4, pp. 76-83, ISSN 1303-2968

Cadore, E.L.; Lhullier, F.L.R.; Brentano, M.A.; Silva, E.M.; Ambrosini, M.B.; Spinelli, R.; Silva, R.F. \& Kruel, L.F.M. (2008a). Hormonal responses to resistance exercise in long-term trained and untrained middle-aged men. Journal of Strength and Conditioning Research, Vol. 22, No. 5 (Sep 2008) pp. 1617-1624, ISSN 1064-8011

Cadore, E.; Lhullier, F.; Brentano, A.; Silva, E.; Ambrosini, M., Spinelli, R., Silva, R.F. \& Kruel, L.F.M. (2008b). Correlations between serum and salivary hormonal concentrations in response to resistance exercise. Journal of Sports Sciences, Vol. 26, No. 10 (Aug 2008) pp. 1067-1072, ISSN 0264-0414

Cadore, E.L.; Brentano, M.A.; Lhullier, F.L.R. \& Kruel, L.F.M. (2008c). Factors concerned with the testosterone and cortisol response to strength training. Revista Brasileira de Medicina do Esporte, Vol. 14, No. 1, (Jan/Fev 2008), pp. 74-78, ISSN 1517-8692

Cadore, E.L.; Lhullier, F.L.; Alberton, C.L.; Almeida, A.P.; Sapata, K.B.; Korzenowski, A.L.; \& Kruel, L.F. (2009a). Salivary hormonal responses to different water-based exercise protocols in young and elderly men. Journal of Strength and Conditioning Research, Vol. 23, No. 9, (Dec 2009), pp. 2695-2701, ISSN 1064-8011

Cadore E.L.; Lhullier, F.; Arias Brentano, A.; Marczwski da Silva, E.; Bueno Ambrosini, M.,;Spinelli, R.; Ferrari Silva, R.; Martins Kruel, L.F. (2009b). Journal of Sports Medicine and Physical Fitness, 49, No. 3 (Sep 2009), pp. 301-307, ISSN 0022-4707

Cadore, E.L.; Pinto, R.S.; Lhullier, F.L.R.; Correa, C.S.; Alberton, C.L.; Pinto, S.S.; Almeida, A.P.V.; Tartaruga, M.P.; Silva, E.M. \& Kruel, L.F.M. (2010). Physiological effects of concurrent training in elderly men. International Journal of Sports Medicine, 31, No. 10 (Oct 2010), pp. 689-697. ISSN 0172-4622 
Calbet, J.A.L.; Navarro, M.A.; Barbany, J.R.; Manso, J.G.; Bonnin, M.R. \& Valero, J. (1993). Salivary steroid changes and physical performance in highly trained cyclists. International Journal of Sports Medicine, Vol. 14, No. 3, (Apr 1993), pp. 111-117, ISSN $0172-4622$

Copeland, J.L.; Consitt, L.A. \& Tremblay, M.S. (2002). Hormonal Responses to endurance and resistance exercise in females aged 19-69 years. The Journal of Gerontology, Vol. 57, No. 4 , (Apr 2002), pp. B158-B165) ISSN 0022-1422

Deschenes, M.R.; Maresh, C.M.; Armstrong, L.E.; Covault, J.; Kraemer, W.J.; Crivello, J.F. (1994). Endurance and resistance exercise induce muscle fiber type specific responses in androgen binding capacity. Journal of Steroid Biochemistry and Molecular Biology Vol. 50, No 3-4, (Aug 1994), pp. 175-179, ISSN 0960-0760

Durand, J.R.; Castracane, V.D.; Hollander, D.B.; Trynieck, J.L.; Bamman, M.M.; O'neal, S.; Hebert, E.P. \& Kraemer, R.R. (2003). Hormonal responses from concentric and eccentric muscle contractions. Medicine and Science in Sports and Exercise 2003, Vol. 35, No. 6, (Jun 2003), pp. 937-943, ISSN 0195-9131

Enea, C.; Boisseau, N.; Mulliez, J.; Millet, C.; Ingrand, I.; Diaz, V. \& Dugué, B. (2009). Effects of menstrual cycle, oral contraception, and training on exercise-induced changes in circulating DHEA-sulphate and testosterone in young women. European Journal of Applied Physiology, Vol. 106, No. 3, (Jun 2009), pp. 365-373, ISSN 1419-6339

Fahrner, C.L. \& Hackney, A.C. (1998). Effects of endurance exercise on free testosterone concentration and binding affinity of sex hormone binding globulin (SHBG). International Journal of Sports Medicine, Vol. 19, No. 1, (Jan 1998), pp. 2-15, ISSN 01724622

Goto, K.; Higashiyama, M.; Ishii, N. \& Takamatsu, K. (2005). Prior endurance exercise attenuates growth hormone responses to subsequent resistance exercise. European Journal of Applied Physiology, Vol. 94, No. 3, (Jun 2005), pp. 333-338, ISSN 1419-6339

Griggs, R.C.; Kingston, W.; Jozefowcz, R.F.; Herr, B.E.; Forbes, G. \& Halliday, D. (1989) Effects of testosterone on muscle mass and muscle protein synthesis. Journal of Applied Physiology, Vol. 66, No 1, (Jan 1989), pp. 498-503, ISSN 8750-7587

Häkkinen, K. \& Pakarinen, A. (1993a). Acute hormonal responses to two different fatiguing heavy-resistance protocols in male athletes. Journal of Applied Physiology, Vol. 74, No. 2, (Feb 1993), pp. 882-887, ISSN 8750-7587

Häkkinen K, Pakarinen A. (1993b). Muscle strength and serum testosterone, cortisol and SHBG concentrations in middle-aged and elderly men and women. Acta Physiologica Scandinavica, Vol. 148, No. 2 (Jun 1993), pp. 199-207, ISSN 0001-6772

Häkkinen, K. \& Pakarinen, A. (1994) Serum hormones and strength development during strength training in middle-aged and elderly males and females. Acta Physiologica Scandinavica,Vol. 150, No. 2 (Feb 1994), pp. 211-219, ISSN 0001-6772

Häkkinen, K. \& Pakarinen, A. (1995). Acute hormonal responses to heavy resistance exercise in men and women at different ages. International Journal of Sports Medicine, Vol. 16, No. 8, (Aug 1995), pp. 507-513, ISSN 0172-4622

Häkkinen K.; Pakarinen, A.; Alen, M.; Kauhanen, H.; Komi, P.V. (1988). Neuromuscular and hormonal adaptations in athletes to strength training in two years. Journal of Applied Physiology, Vol. 65, No. 6, (Dec 1988), pp. 2406-2412, ISSN 8750-7587

Häkkinen, K.; Pakarinen, A.; Newton, R.U.; Kraemer, W.J. (1998). Acute hormonal responses to heavy resistance lower and upper extremity exercise in young versus old men. 
European Journal of Applied Physiology Vol. 77, No. 4, (Mar 1998), pp. 312-19 ISSN 1419-6339

Häkkinen, K.; Pakarinen, A.; Kraemer, W.J.; Newton, R.U. \& Alen, M. (2000). Basal concentrations and acute responses of serum hormones and strength development during heavy resistance training in middle-aged and elderly men and women. Journal of Gerontology: Biological Sciences, Vol. 55, No. 2, (Feb 2000), pp. B95-B105, ISSN 0022-1422

Häkkinen, K.; Pakarinen, A.; Kraemer, W.J.; Häkkinen, A.; Valkeinen, H. \& Alen, M. (2001a). Selective muscle hypertrophy, changes in EMG and force, and serum hormones during strength training in older women. Journal of Applied Physiology, Vol. 91, No. 2, (Aug 2001), pp. 569-80, ISSN 8750-7587

Häkkinen, K.; Kraemer, W.J.; Newton, R.U. \& Alen, M. (2001b). Changes in electromyographic activity, muscle fibre and force production characteristics during heavy resistance/power strength training in middle-aged and older men and women. Acta Physiologica Scandinavica, Vol .171, No 1, (Jan 2001), pp. 51-62, ISSN 0001-6772

Hansen, S.; Kvorning, T.; Kjaer, M. \& Sjogaard, G. (2001). The effect of short-term strength training on human skeletal muscle: the importance of physiologically elevated hormone levels. Scandinavian Journal of Medicine and Science in Sports, Vol. 11, No. 6, (Dec 2001), pp. 347-54. ISSN 0905-7188

Harris, B.; Cook, N.J.; Walker, R.F.; Read, G.F.; Riad-Fahmy, D. (1989). Salivary steroids and psychometric parameters in male marathon runners. British Journal of Sports Medicine; 23 (2): 89-93. ISSN 0306-3674

Hickson, R.C.; Hidaka, K.; Foster, C.; Falduto, M.T. \& Chatterton Jr, R.T. (1994). Successive time courses of strength development and steroid hormone responses to heavyresistance training. Journal of Applied Physiology, Vol. 76 No. 2, (Feb 1994), 663-670, ISSN 8750-7587

Hoffman, J.R.; Im, J.; Rundell, K.W.; Kang, J.; Nioka, S.; Speiring, B.A.; Kime, R. \& Chance, B. (2003). Effects of muscle oxygenation during resistance exercise on anabolic hormone response. Medicine and Science in Sports and Exercise Vol. 35, No. 11, (Nov 2003), pp. 1929-34. ISSN 0195-9131

Hu, Y.; Asano, K.; Mizuno, K.; Usuki, S.; Kawamura, Y. (1999). Serum testosterone responses to continuous and intermittent exercise training in male rats. International Journal of Sports Medicine, Vol. 20, No. 1 (Jan 1999), pp. 12-16, ISSN 0172-4622

Inoue, K.; Yamasaki, T.; Fushiki, T.; Kano, T.; Moritani, T.; Itoh, K. \& Sugimoto E. (1993). Rapid increase in the number of androgen receptors following electrical stimulation of the rat muscle. European Journal of Applied Physiology, Vol. 66, No. 2 (Feb. 1993), pp. 134-40, ISSN 1419-6339

Inoue, K.; Yamasaki, T.; Fushiki, T, Okada, Y. \& Sugimoto, E. (1994). Androgen receptor antagonist suppresses exercise-induced hypertrophy of skeletal muscle. European Journal of Applied Physiology, Vol. 69, No. 1, (Jan 1994), pp. 88-91, ISSN 1419-6339

Izquierdo, M.; Häkkinen, K.; Ibañez, J.; Garrues, M.; Antón, A.; Zúniga, A.; Larrión, J.L. \& Gorostiaga, E.M. (2001). Effects of strength training on muscle power and serum hormones in middle-aged and older men. Journal of Applied Physiology, Vol. 90, No. 4, (Apr 2001), pp. 1497-1507, ISSN 8750-7587 
Izquierdo, M.; Ibañez, J.; Häkkinen, K.; Kraemer, W.J.; Ruesta, M. \& Gorostiaga, E.M. (2004). Maximal strength and power, muscle mass, endurance and serum hormones in weightlifters and road cyclists. Journal of Sports Sciences, Vol. 22, No. 5, (May 2004), pp. 465-478, ISSN 0264-0414

Izquierdo, M.; Ibañez, J.; González-Badillo, J.J.; Häkkinen, K.; Ratamess, N.A.; Kraemer, W.J.; French, D.N.; Eslava, J.; Altadill, A.; Asiain, X. \& Gorostiaga, E.M. (2006). Differential effects of strength training leading to failure versus not to failure on hormonal responses, strength or power gains. Journal of Applied Physiology Vol. 100, No. 5, (May 2006), pp. 1646-1656, ISSN 8750-7587

Kadi, F.; Bonnrud, P.; Eriksson, A. \& Thornell, L.E. (2000). The expression of androgen receptors in human neck and limb muscles: effects of training and selfadministration of androgenic steroids. Histochemistry and Cell Biology, Vol. 113, No 1, (Jan 2000), pp. 25-29, ISSN 0948-6143

Kemmler, W.K.; Lauber, D.; Engelke, K. \& Weineck, J. (2004). Effects of single- vs. multipleset resistance training on maximun strength and body composition in trained postmenopausal women. Journal of Strength and Conditioning Research, Vol. 18, No. 4, (Nov 2004), pp. 689-694, ISSN 1064-8011

Kraemer, R.R.; Hollander, D.B.; Reeves, G.V.; Francois, M.; Ramadan, Z.G.; Meeker, B.; Tryniecki, J.L.; Hebert, E.P. \& Castracane, V.D. (2006). Similar hormonal responses to concentric and eccentric muscle actions using relative loading. European Journal of Applied Physiology Vol. 96, No. 5, (Mar 2006), pp. 551-557, ISSN 1419-6339

Kraemer, W.J.; Marchitelli, L.J.; Gordon, S.E.; Harman, E.; Dziados, J.E,.; Mello, R.; Frykman, P.; McCurry, D. \& Fleck, S.J. (1990). Hormonal and growth factor responses to heavy resistance exercise protocols. Journal of Applied Physiology, Vol. 69, No. 4, (Oct 1990), pp. 1442-1450, ISSN 8750-7587

Kraemer, W.J.; Fry, A.C.; Warren, B.J.; Stone, M.H.; Fleck, S.J.; Kearney, J.T.; Conroy, B.P.; Maresh, C.M.; Weseman, C.A.; Triplett, N.T. \& Gordon, S.E. (1992).Acute hormonal responses in elite junior weightlifters. International Journal of Sports Medicine, Vol. 13, No. 2, (Feb 1992), pp. 103-109, ISSN 0172-4622

Kraemer, W.J.; Fleck, S.J.; Dziados, J.E.; Harman, E.A.; Marchitelli, L.J.; Gordon, S.E.; Mello, R.; Frykman, P.N.; Koziris, L.P. \& Triplett, N.T. (1993). Changes in hormonal concentrations after different heavy-resistance exercise protocols in women. Journal of Applied Physiology, Vol. 75, No. 2 (Aug 1993), pp. 494-504, ISSN 8750-7587

Kraemer, W.J.; Patton, J.F.; Gordon, S.E.; Harman, E.A.; Deschenes, M.R.; Reynolds, K.; Newton, R.U.; Triplett, N.T. \& Dziados, J.E. (1995). Compatibility of high-intensity strength and endurance training on hormonal and skeletal muscle adaptations. Journal of Applied Physiology Vol. 78, No 3, (Mar 1995), pp. 976-989, ISSN 8750-7587

Kraemer, W.J.; Staron, R.S.; Hagerman, F.C.; Hikida, R.S.; Fry, A.C.; Gordon, S.E.; Nindl, B.C.; Gothshalk, L.A.; Volek, J.S.; Marx, J.O.; Newton, R.U. \& Häkkinen, K. (1998). The effects of short-term resistance training on endocrine function in men women. European Journal of Applied Physiology 1998;Vol. 78, No. 1, (Jun 1998), pp. 69-76, ISSN 1419-6339

Kraemer, W.J.; Häkkinen, K.; Newton, R.U.; Nindl, B.C.; Volek, J.S.; McCormick, M.; Gothshalk, L.A.; Gordon, S.E.; Fleck, S.J.; Campbell, W.W.; Putukian, M. \& Evans, W.J. (1999). Effects of resistance training on hormonal response patterns in younger 
vs. older men. Journal of Applied Physiology Vol. 87, No. 3, (Sep 1999), pp. 982-992, ISSN 8750-7587

Kraemer, W.J. \& Ratamess, N.A. (2005). Hormonal responses and adaptation to resistance exercise and training Sports Medicine, Vol. 35, No. 4, pp. 339-361, ISSN 0193-1849

Lu, S.; Lau, C.; Tung, Y.; Huang, S.; Chen,Y.; Shih, H., Tsai, S.C.; Lu, C.C.; Wang, S.W.; Chen, J.J.; Chien, E.J.; Chien, C.H. \& Wang, P.S. (1997). Lactate and the effects of exercise on testosterone secretion: evidence for the involvement of cAMP-mediated mechanism. Medicine and Science in Sports and Exercise, Vol. 29, No. 8, (Aug 1997), pp. 1048-1054, ISSN 0195-9131

Maïmoun, L.; Lumbroso, S.; Manetta, J.; Paris, F.; Leroux, J.L. \& Sultan, C. (2003). Testosterone is significantly reduced in endurance athletes without impact on bone mineral density. Hormone Research Vol. 59, No. 6, pp. 285-292, ISSN 0301-0163

Marx, J.O.; Ratamess, N.A.; Nindl, B.C.; Gotshalk, L.A.; Volek, J.S.; Dohi, K.; Bush, J.A.; Gómez, A.L.; Mazzetti, S.A.; Fleck, S.J.; Newton, R.U. \& Häkkinen, K. (2001). Lowvolume circuit versus high-volume periodized resistance training in women. Medicine and Science in Sports and Exercise, Vol. 33, No. 4, (Apr 2001), pp. 635-643, ISSN 0195-9131

McCaulley, G.O.; McBride, J.M.; Cormie, P.; Hudson, M.B.; Nuzzo, J.L.; Quindry, J.C.; \& Triplett, N.T. (2009). Acute hormonal and neuromuscular to hypertrophy, strength and power type resistance exercise. European Journal of Applied Physiology, Vol. 105, No. 5, (Mar 2009), pp. 695-704, ISSN 1419-6339

Meskaitis, V.J.; Harman, F.S.; Volek, J.S.; Nindl, B.C.; Kraemer, W.J.; Weinstok, D. \& Deaver, D.R. (1997) Effects of exercise on testosterone and nitric oxide production in the rats testis. The Journal of Andrology Supplement 1997; p. 31, ISSN 0196-3635

Nicklas, B.J.; Ryan, A.S.; Treuth, M.M.; Harman, S.M.; Blackman, M.R.; Hurley, B.F. \& Rogers, M.A. (1995). Testosterone, growth hormone and IGF-I responses to acute and chronic resistive exercise in men aged 55-70 years. International Journal of Sports Medicine, Vol.16, No. 7, (Oct 1995), pp. 445-450, ISSN 0172-4622

Raastad, T.; Glomsheler, T.; Bjoro, T. \& Hallen, J. (2003). Recovery of skeletal muscle contractility and hormonal responses to strength exercise alter two weeks of highvolume strength training. Scandinavian Journal of Medicine and Science in Sports, Vol. 13, No. 3 (Jun 2003), pp.159-168, ISSN 0905-7188

Ramos, E.; Frontera, W.R.; Llopart, A. \& Feliciano, D. (1998). Muscle strength and hormonal levels in adolescents: gender related differences. International Journal of Sports Medicine 1998; Vol. 19, No 8, (Nov 1998), pp. 526-531, ISSN 0172-4622

Ratamess, N.A.; Kraemer, W.J.; Volek, J.S.; Maresh, C.M.; Vanheest, J.L.; Sharman, M.J.; Rubin, M.R.; French, D.N.; Vescovi, J.D.; Silvestre, R.; Hatfield, D.L.; Fleck, S.J. \& Deschenes, M.R. (2005). Androgen receptor content following heavy resistance exercise in men. Journal of Steroid Biochemistry and Molecular Biology, Vol. 93, No. 1, (Jan 2005), pp. 35-42, ISSN 0960-0760

Ryan, A.S.; Treuch, M.S.; Rubin, M.A.; Miller, J.P.; Nicklas, B.J.; Landis, D.M.; Pratley, R.E.; Libanati, C.R.; Gundberg, C.M. \& Hurley, B.F. (1994) Effects of strength training on bone mineral density: hormonal and bone turnover relationships. Journal of Applied Physiology, Vol. 77, No. 4, (Oct 1994), pp.1678-1684, ISSN 8750-7587

Smilios, I.; Pilianidis, T.; Karamouzis, M.; Parlavantzas, A. \& Tokmakidis SP. (2007). Hormonal responses after strength endurance resistance exercise protocol in young 
and elderly males. International Journal of Sports Medicine, Vol. 28, No. 5, (May 2007), pp. 401-406, ISSN 0172-4622

Smilios, I.; Pilianidis, T.; Karamouzis, M. \& Tokmakidis, S. Hormonal responses after various resistance exercise protocols. Medicine and Science in Sports and Exercise, Vol 35, No. 4, (Apr 2003), pp. 644-654, ISSN 0195-9131

Staron, R.S.; Karapondo, D.L.; Kraemer, W.J.; Fry, A.C.; Gordon, S.E.; Falkel, J.E.; Hagerman, F.C. \& Hikida, R.S. (1994). Skeletal muscle adaptations during early phase of heavy-resistance training in men and women. Journal of Applied Physiology, Vol. 76, No. 3, (Mar 1994), pp. 1247-1255, ISSN 8750-7587

Strüder, H.K.; Hollmann, W.; Platen, P.; Rost, R.; Wiecker, H.; Kirchhof, O. \& Weber, K. (1999). Neuroendocrine system and mental function in sedentary and endurancetrained elderly males. International Journal of Sports Medicine, Vol. 20, No. 3 (Apr 1999), pp. 159-166, ISSN 0172-4622

Tremblay, M.S.; Copeland, J.L. \& Van Helder, W. (2004). Effect of training status and exercise mode on endogenous steroid hormones in men. Journal of Applied Physiology, Vol. 96, No. 2, (Feb 2004), pp. 531-539, ISSN 8750-7587

Tremblay, M.S.; Copeland, J.L. \& Van Helder, W. (2005). Influence of exercise duration on post-exercise steroid hormone responses in trained males. European Journal of Applied Physiology, Vol.94, No. 5-6, (Aug 2005), pp. 505-513, ISSN 1419-6339

Tsolakis, C.K.; Vagenas, G.K. \& Dessypris, A.G. (2004). Strength adaptations and hormonal responses to resistance training and detraining in preadolescent males. Journal of Strength and Conditioning Research, Vol. 18, No. 3, (Aug 2004), pp.625-629, ISSN 1064-8011

Willoughby, D.S. \& Taylor, L. (2004). Effects of sequential bouts of resistance exercise on androgen receptor expression Medicine and Science in Sports and Exercise, Vol. 36, No. 9, (Sep 2004), pp.1499-1506, ISSN 0195-9131 


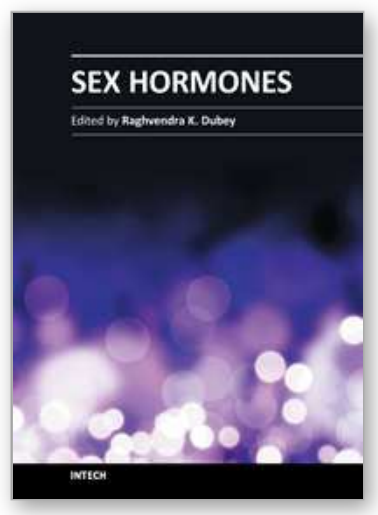

\section{Sex Hormones}

Edited by Prof. Raghvendra Dubey

ISBN 978-953-307-856-4

Hard cover, 430 pages

Publisher InTech

Published online 08, February, 2012

Published in print edition February, 2012

Sex Hormones not only regulate reproductive function, but they also play a prominent role in the biology and physiology of several organs/tissues and in the pathophysiology of several diseases. During the last two decades, the information on the mechanisms of action of sex hormones, such as estrogens and androgens, has rapidly evolved from the conventional nuclear receptor dependent mechanisms to include additional nonnuclear, non-genomic and receptor-independent mechanisms. This highlights the need to update the current knowledge on sex hormones and their mode of action. Increasing evidence that exogenous/epigenetic factors can influence sex hormone production and action highlights the need to update our knowledge on the mechanisms involved. This book provides a systematic and updated overview of the male/female sexhormones and their impact in the biology and physiology of various organs. Additionally, the book discusses their positive and negative association with the pathophysiology of various diseases (e.g. osteoporosis, cardiovascular-disease, hypogonadism, reproduction, cancer) and their therapeutic potential.

\section{How to reference}

In order to correctly reference this scholarly work, feel free to copy and paste the following:

Eduardo Lusa Cadore and Luiz Fernando Martins Kruel (2012). Acute and Chronic Testosterone Responses to Physical Exercise and Training, Sex Hormones, Prof. Raghvendra Dubey (Ed.), ISBN: 978-953-307-856-4, InTech, Available from: http://www.intechopen.com/books/sex-hormones/acute-and-chronic-testosteroneresponses-to-physical-exercise-and-training

\section{INTECH}

open science | open minds

\section{InTech Europe}

University Campus STeP Ri

Slavka Krautzeka 83/A

51000 Rijeka, Croatia

Phone: +385 (51) 770447

Fax: +385 (51) 686166

www.intechopen.com

\section{InTech China}

Unit 405, Office Block, Hotel Equatorial Shanghai

No.65, Yan An Road (West), Shanghai, 200040, China

中国上海市延安西路65号上海国际贵都大饭店办公楼 405 单元

Phone: +86-21-62489820

Fax: +86-21-62489821 
(C) 2012 The Author(s). Licensee IntechOpen. This is an open access article distributed under the terms of the Creative Commons Attribution 3.0 License, which permits unrestricted use, distribution, and reproduction in any medium, provided the original work is properly cited. 